Vitalii Kondratenko,

Dr. Sc, Associate Professor, Volodymyr Vynnychenko Central Ukrainian State Pedagogical University, Ukraine

Olena Okopnyk,

Ph.D., Associate Professor, Volodymyr Vynnychenko Central Ukrainian State Pedagogical University, Ukraine

Linda Ziganto,

Juraj Dobrila University of Pula, Croatia

Aleksy Kwilinski,

Ph.D., The London Academy of Science and Business, United Kingdom

\title{
INNOVATION DEVELOPMENT AND EFFICIENCY OF PUBLIC ADMINISTRATION: MANAGEMENT AND LEGISLATION FEATURES
}

\begin{abstract}
The paper deals with the analysis of the impact of public administration on the innovation development. With purposes to identify the main scientific directions of analysis among the scientific community, the authors did the bibliometric study. For the reviews, the authors selected 1167 papers which indexing in Scopus. For the visualising the findings of bibliometric analysis, the VOSviewer was used. The results allow allocating 10 clusters of scientific directions which analysed the issues of innovations and public administrations. The first most significant clusters could "innovation" analysed the efficiency of the public administration through the effectiveness of innovation implementation. The second clusters connected with the government innovation policy and located close to the first clusters. The third cluster "public administration» involved 40 items and 4699 links. The scientists with Italian and American affiliations had the most significant shares of papers. At the same time, the European funding allocated the most significant share of financing such research. The hypothesis of the investigation was checking the linking between levels of innovation development and countries' rating on the efficiency of public administration using the correlation analysis and least square model. For the checking hypothesis, the authors used the software EViews 11. The authors analysed the Worldwide Governance Indicators as the base indicators for the assessment of public administration efficiency. For the analysis, the authors used data for EU countries and Ukraine. As Ukraine has started the integration process, the Ukrainian policy should be synchronised with the EU. The findings proved the correlation between variables. Thus, the increasing of government efficiency and the rule of law lead to increasing by 0,094 and 0,043 points the level of innovation development of the country corresponding. At the same time, the increasing regulation policy provoke the increase of innovation development by 0,08 points. The less impact had the variables as follows: sustainability competitiveness of the country and volume of expenditure on research and development. After analysis of the empirical data, the reviews of the management and legal instruments was done. Considering the EU experience, the authors identified the system of tools which lead to increasing of public administration efficiency as follows: legislation on property rights, anti-corruption directives, digitalisation of government authorities at all levels. For the future investigation, the time and range of the countries should be extended.
\end{abstract}

Keywords: governance, management, law, property right, innovation.

Introduction. The strengthening of global competitiveness provokes the government to transform from the traditional to innovation model of the country's economic development. Thus, the range of the common indicators developed by the rating agencies with the purpose to estimate the country's competitiveness. Besides, the ongoing Industry Revolution leads to extending innovations and considering them in management at all levels. In this case, governance should understand the impact of innovations on public administration and developed relevant legislative mechanisms and instruments to attract and support innovations.

Literature Review. Considering the findings of the bibliometric analysis, the numbers of papers on «public administration» and «innovations» have been increasing for the last ten years. Thus, in 2019 the numbers of documents increased in twice compare with 2009. At the same time, in 2009, 2012, 2014 and

Cite as: Kondratenko, V., Okopnyk, O., Ziganto, L., \& Kwilinski, A. (2020). Innovation Development of Public Administration: Management and Legislation Features. Marketing and Management of Innovations, 1, 8794. https://doi.org/10.21272/mmi.2020.1-06 

Legislation Features

2018, the numbers of paper decreased compared with the relevant previous years. Publication activity in Scopus on innovations and public administration showed in Figure 1.

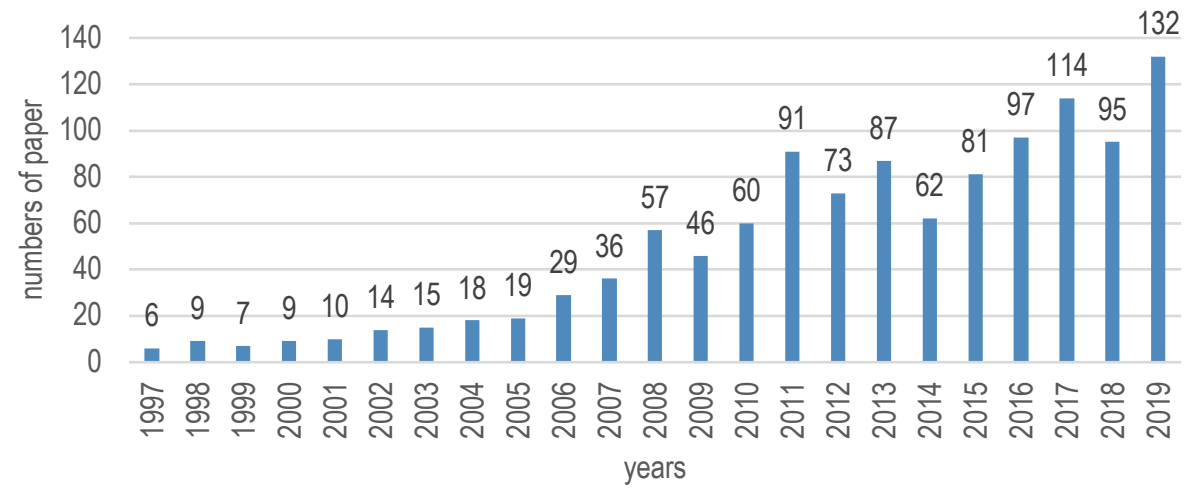

Figure 1. Publication activity in Scopus on innovations and public administration Sources: developed by authors using Scopus Tools Analyses

Considering the findings, the scientists with Italian and United Kingdom affiliations had the most significant share of paper on innovations and public administration in Scopus. Thus, among 1167 papers $12,43 \%$ and $12,25 \%$ of the documents were written by the scientists from Italy of the United Kingdom (Table 1).

Table 1. Papers in Scopus on innovations and public administration by country

\begin{tabular}{|c|c|c|}
\hline Country & Numbers of documents, unit & Share, $\%$ \\
\hline Italy & 145 & $12,43 \%$ \\
\hline United States & 143 & $12,25 \%$ \\
\hline Russian Federation & 120 & $10,28 \%$ \\
\hline Spain & 116 & $9,94 \%$ \\
\hline United Kingdom & 69 & $5,91 \%$ \\
\hline Canada & 64 & $5,48 \%$ \\
\hline Netherlands & 46 & $3,94 \%$ \\
\hline Australia & 39 & $3,34 \%$ \\
\hline Brazil & 37 & $3,17 \%$ \\
\hline Germany & 35 & $3,00 \%$ \\
\hline TOTAL & 1167 & \\
\hline
\end{tabular}

Sources: developed by authors using Scopus Tools Analyses

Thus, considering the results, the most cited papers (84 citations) among Italian scientists were published in high ranked Journal «Public Administration Review» (SNIP 2,857 in 2018). The positive dynamic of investigation on abovementioned issues could be explained by the massive volume of financing, which invested by the EU government. Considering the data in Table 2, the European Commission financed ten investigations, National Natural Science Foundation of China and Social Sciences and Humanities Research Council of Canada - 7 documents, less European Regional Development Fund and National Science Foundation.

Besides, the most cited paper (more than 220 citations, among all) was published by the authors from Spain and Mexico Criado J. I., Sandoval-Almazan R. and Gil-Garcia J. R. in 2013. In the paper (Criado et 

Legislation Features

al., 2013) they proved the positive impact of social media on innovations in governance. The team of American authors in the article (Tolbert et al., 2018) prooved the linking between innovation policy and egovernment in the United States.

Table 2. Papers in Scopus on innovations and public administration by country

\begin{tabular}{|l|c|}
\hline \multicolumn{1}{|c|}{ Sponsors } & Numbers of documents, unit \\
\hline European Commission & 10 \\
\hline National Natural Science Foundation of China & 7 \\
\hline Social Sciences and Humanities Research Council of Canada & 7 \\
\hline European Regional Development Fund & 5 \\
\hline National Science Foundation & 4 \\
\hline
\end{tabular}

Sources: developed by authors using Scopus Tools Analyses

The results of co-occurrence analyses by the keywords of the selected papers on the public administration and innovation development allow identifying 10 clusters (Figure 2).

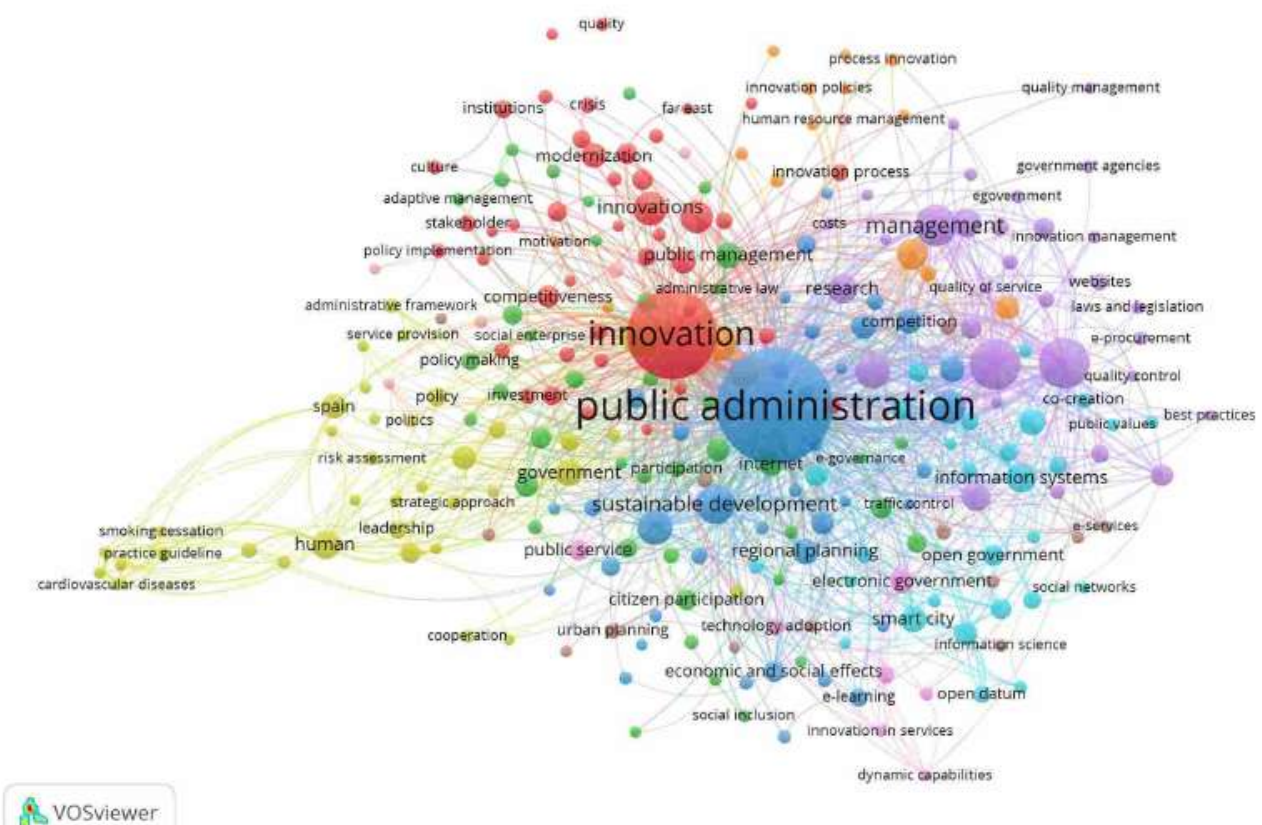

Figure 2. Co-occurrence analyses by the keywords «innovation development» and «public administration» among selected papers which indexed by Scopus

Sources: developed by authors using VOSviewer and Scopus

Among 10 clusters the first most prominent clusters could be named as «innovation». The scientists of this clusters analysed the public administration through the efficiency of innovation implementation. The second clusters connected with the government innovation policy and located close to the first clusters. The third cluster involved 40 items and 4699 links. This cluster could be called «public administration». 

Legislation Features

The findings proved that scientific community around the world analysed the public administration and innovations from the different points of views: social and economic development of the national economy (Bilan et al., 2019e; Vasylieva et al., 2017b, 2013; ; Dalevska et al, 2019;); the influence of bank and financial system on innovation development (Bilan et al., 2019a; Buriak et al., 2015; Vasylieva et al., 2017a; Bilan et al., 2019d; Kaźmierczyk and Chinalska, 2018; Tkachenko et al., 2019b; Brychko et al., 2018); country's brand management (Bilan et al., 2019b); macroeconomic stability (Bilan et al., 2019c; Dementyev and Scherbakov, 2017); green innovations and energy policy (Yevdokimov et al., 2018; Pimonenko et al., 2017; Chygryn et al., 2019; Pajak et al., 2017); new management trends (Leonov et al., 2017).

The scientists of the first clusters (Figure 1) Scupola A. and Zanfei A. (2016) using Hartley's model proved the hypothesis between innovation tools and efficiency of governance. The scientists in the paper (Arduini et al., 2010; Hrytsenko et al., 2018) proved the necessity to develop competence to develop the skills to use innovative technologies in governance at all levels. Ahn M. J. and Bretschneider S. (2011) proved that innovation technology declined the corruption and bureaucracy among the government authorities. The scientists in the papers (Smith, 2010; Mergel et al., 2013; Vasilyeva et al., 2017; Vasyl'eva et al., 2017) proved that open innovations increased the openness of the government. Despite the numerous investigations on linking between innovations and efficiency of public administration, most scientists analyse the efficiency information technology as the innovations. At the same time, the aspects of management and legislation features have not developed. Besides, most papers focused on Italian or American conditions. In this case, under this investigation, the authors analysed the linking between innovations and efficiency of public administration on examples of all EU countries and Ukraine.

Methodology and research methods. Under the investigation, the few steps were done as follows:

1. The bibliometric analysis presented in the Literature review. For the study, the VOSviewer and Scopus Tools analyses were used.

2. Selecting a variable for analyses. Under the study, the database was used as follows: World Data Bank, Eurostat, Worldwide Governance Indicators

3. Considering the findings, identify the management and legislation instruments, which increased the efficiency of innovations implementation in public authorities.

For checking the general hypothesis about linking between the innovation development and public administration efficiency, the authors used correlation analysis and the least square model. For that purpose, the software EViews 11 was used. The explanations of the variables were presented in Table 3.

Table 3. The variables for analysis

\begin{tabular}{|c|c|c|}
\hline Variables & Indicators & Source \\
\hline $\begin{array}{l}\text { Governance Efficiency as a parameter of } \\
\text { efficiency of public administration }\end{array}$ & GE & \multirow{3}{*}{$\begin{array}{l}\text { The Worldwide Governance Indicators (WGI) } \\
\text { project reports (Kaufmann et al., 2010-2019) }\end{array}$} \\
\hline Rule of Law & $\mathrm{RL}$ & \\
\hline Regulation Policy & $\mathrm{RP}$ & \\
\hline $\begin{array}{l}\text { Intramural R\&D expenditure (GERD) by sectors of } \\
\text { performance as the indicator of innovations }\end{array}$ & R\&D & $\begin{array}{l}\text { Intramural R\&D expenditure } \\
\text { (Eurostat, 2019) }\end{array}$ \\
\hline $\begin{array}{l}\text { Global Innovation Index indicates the innovation } \\
\text { development of the country }\end{array}$ & GII & The Global Innovation Index, 2019 \\
\hline $\begin{array}{l}\text { Global Sustainability Competitiveness Index as a } \\
\text { dependent variable }\end{array}$ & $\mathrm{GSCl}$ & $\begin{array}{l}\text { The Global Sustainability Competitiveness } \\
\text { Index, } 2019\end{array}$ \\
\hline
\end{tabular}

Sources: compiled by authors

At the last stage, considering the results from meta-analysis and the correlations analysis, the analysis of legal and management instrument to increase the efficiency of innovations was compiled. 

Legislation Features

Results. At the first stage, the descriptive statistic was done. The findings of the analysis presented in Table 4.

At the next stage, all data were normalised. The checking data of stationarity allow accepting the hypothesis that all data are stationarity.

Table 4. Descriptive statistic of selected variables

\begin{tabular}{|c|c|c|c|c|c|c|}
\hline Variables & GII & GE & RL & RP & R\&D & GSCI \\
\hline Mean & 49,47 & 1,06 & 1,066 & 1,11 & 10269,75 & 49,78 \\
\hline Mediation & 49,3 & 1,07 & 1,077 & 1,08 & 2258,47 & 49,9 \\
\hline Maximum & 63,8 & 2,17 & 2,11 & 2,04 & 99553,62 & 62,8 \\
\hline Minimum & 35,7 & $-0,65$ & $-0,81$ & $-0,63$ & 58,7 & 0,54 \\
\hline Standard Deviation & 7,63 & 0,66 & 0,69 & 0,56 & 18904,14 & 6,14 \\
\hline
\end{tabular}

Sources: compiled by authors

The Correlation Matrix allows identifying the multicollinearity of selected variables. As multicollinearity makes the significant parameters insignificance by increasing the standards error. The high rate of correlation between two parameters could indicate about multicollinearity. The Correlation Matrix of variables in Table 3 showed in Table 5.

Table 5. Correlation Matrix of selected variables

\begin{tabular}{|c|c|c|c|c|c|c|}
\hline Variables & GII & GE & GSCl & R\&D & RL & RP \\
\hline GII & 1 & & & & & \\
\hline GE & 0,57 & 1 & & & & \\
Probability & $(0,000)$ & & & & & \\
\hline GSCl & 0,43 & 0,46 & 1 & & & \\
Probability & $(0,000)$ & $(0,000)$ & & & & \\
\hline R\&D & 0,42 & 0,36 & 0,18 & 1 & & \\
Probability & $(0,034)$ & $(0,001)$ & $(0,02)$ & & & \\
\hline RL & 0,50 & 0,44 & 0,46 & 0,34 & 1 & \\
Probability & $(0,000)$ & $(0,000)$ & $(0,000)$ & $(0,000)$ & & \\
\hline RP & 0,49 & 0,47 & 0,48 & 0,33 & 0,53 & 1 \\
Probability & $(0,000)$ & $(0,000)$ & $(0,000)$ & $(0,000)$ & $(0,000)$ & \\
\hline
\end{tabular}

Sources: compiled by authors.

The findings in Table 4 reject the hypothesis about multicollinearity of variables. At the last stage, the checking of the variables' impact on the country's innovation development was done using the least square model.

Table 6. Impact of variables on Global Innovation Index

\begin{tabular}{|c|c|c|c|c|}
\hline Variables & Coefficient & Standard Error & t-statistic & Probability \\
\hline GE & 0,094 & 0,004 & 2,156 & $0,000^{*}$ \\
\hline GSCl & 0,003 & 0,017 & 0,035 & $0,034^{* *}$ \\
\hline R\&D & 0,019 & 0,003 & 5,282 & $0,041^{* *}$ \\
\hline RL & 0,043 & 0,038 & 1,136 & $0,001^{*}$ \\
\hline RP & 0,08 & 0,033 & 2,247 & $0,002^{*}$ \\
\hline constant & 1,63 & 0,03 & 54,33 & $0,000^{*}$ \\
\hline
\end{tabular}

Note: ${ }^{*},{ }^{* \star}$ significance at level $1 \%$ and $5 \%$ corresponding.

Sources: compiled by authors. 

Legislation Features

The R-squared coefficient was 0,89 , which mean that empirical results were significant. Thus, the obtained data allow identifying that rule of law, government efficiency and regulatory policy were significant at $1 \%$, and expenditure on research on development and sustainability competitiveness of the country were significant at $5 \%$ level.

Thus, increasing by one point of government efficiency and the rule of law leads to increasing by 0,094 and 0,043 points the level of innovation development of the country corresponding. At the same time, the increasing regulation policy provoke the increase of innovation development by 0,08 points. The less impact had the variables as follows: sustainability competitiveness of the country and volume of expenditure on research and development.

The empirical results proved that innovation development of the countries' related to government efficiency. Besides, the rule of law and regular policy had a statistically significant impact on government efficiency. In this case, Ukraine, as a country which planned to join the EU should analyse and synchronise the national legislation with the EU normative base.

At the first step, the government should accept the block of anti-corruption regulations which should correspond to the EU legislation. Such changes lead to increasing the openness of the government and decrease the index of corruption in the country. Besides, the regulation of property rights should be implemented at the national level, which boosts the developing of innovations in Ukraine. Noted, that beginning the Ukrainian government had already started to the digitalisation of government at all levels. Unfortunately, that process was not systematically. Only a few services allowed for using among society. In this case, Ukraine should analyse the Estonian experience in this direction.

Conclusions. Considering the results of the bibliometric analysis, ten clusters of the scientific directions on investigation the innovation development and government efficiency could allocate. The $t$ first most significant groups «innovation» involved scientists who analysed the public administration through the effectiveness of innovations implementation. The second clusters connected with the government innovation policy and located close to the first clusters. The third cluster «public administration» focused on analysis different dimensions on the efficiency of government efficiency. The findings proved the correlation between selected variables. The increasing of government efficiency and the rule of law lead to increasing by 0,094 and 0,043 points the level of innovation development of the country corresponding. Besides, the increasing regulation policy provoke the increase of innovation development by 0,08 points. Considering the EU experience, the system of instruments which lead to increasing of public administration efficiency could be proposed as follows: legislation on property rights, anti-corruption directives, digitalisation of government authorities at all levels. For the future investigation, the time and range of the countries should be extended.

Author Contributions: conceptualisation, methodology, investigation, visualisation V. K, L. Z., A.K. and 0.0 .

\section{References}

Ahn, M. J., \& Bretschneider, S. (2011). Politics of e-government: E-government and the political control of bureaucracy. Public Administration Review, 71(3), 414-424. [Google Scholar] [CrossRef]

Akulich, M. \& Kaźmierczyk, J. (2018) The socio-economic approach to the study of main economic systems. Socialism and capitalism. Part 1. Management, 22(1), 238-250. [Google Scholar] [CrossRef]

Arduini, D., Belotti, F., Denni, M., Giungato, G., \& Zanfei, A. (2010). Technology adoption and innovation in public services the case of e-government in Italy. Information economics and policy, 22(3), 257-275. [Google Scholar] [CrossRef]

Bilan, Y., Brychko, M., Buriak, A., \& Vasilyeva, T. (2019). Financial, business and trust cycles: The issues of synchronization. Zbornik Radova Ekonomskog Fakultet Au Rijeci, 37(1), 113-138. [Google Scholar] [CrossRef] 

Legislation Features

Bilan, Y., Kuzmenko, O., Boiko, A. (2019a). Research on the impact of Industry 4.0 on entrepreneurship in various countries worldwide. In Proceedings of the 33rd International Business Information Management Association Conference, IBIMA 2019: Education Excellence and Innovation Management through Vision 2020, Granada, Spain, 10-11 April 2019; pp. 2373-2384

Bilan, Y., Lyeonov, S., Lyulyov, O., \& Pimonenko, T. (2019b). Brand management and macroeconomic stability of the country. Polish Journal of Management Studies, 19. [Google Scholar]

Bilan, Y., Raisiene, A. G., Vasilyeva, T., Lyulyov, O., \& Pimonenko, T. (2019c). Public Governance efficiency and macroeconomic stability: examining convergence of social and political determinants. [Google Scholar] [CrossRef]

Bilan, Y., Rubanov, P., Vasylieva, T., \& Lyeonov, S. (2019d). The influence of industry 4.0 on financial services: Determinants of alternative finance development. Polish Journal of Management Studies, 19. [Google Scholar] [CrossRef]

Bilan, Y., Vasilyeva, T., Lyulyov, O., \& Pimonenko, T. (2019e). EU vector of Ukraine development: linking between macroeconomic stability and social progress. International Journal of Business and Society, 20(2). [Google Scholar]

Brychko, M., \& Semenog, A. (2018). Efficiency as a new ideology of trust-building corporate governance. Business and Economic Horizons. Prague Development Center. [Google Scholar] [CrossRef]

Buriak, A. V, Lyeonov, S. V, \& Vasylieva, T. A. (2015). Systemically important domestic banks: an indicator-based measurement approach for the Ukrainian banking system. Prague Economic Papers, 24(6), 715-728. [Google Scholar] [CrossRef]

Chygryn, O., Pimonenko, T., Luylyov, O., \& Goncharova, A. (2018). Green Bonds like the Incentive Instrument for Cleaner Production at the Government and Corporate Levels: Experience from EU to Ukraine. Journal of Environmental Management and Tourism, 9(7), 1443-1456. [Google Scholar] [CrossRef

Criado, J. I., Sandoval-Almazan, R., \& Gil-Garcia, J. R. (2013). Government innovation through social media. [Google Scholar] [CrossRef]

Dalevska, N., Khobta, V., Kwilinski, A., \& Kravchenko, S. (2019). A model for estimating social and economic indicators of sustainable development. Entrepreneurship and Sustainability Issues, 64), 1839-1860. [Google Scholar] [CrossRef]

Eurostat. (2019). Intramural R\&D expenditure (GERD) by sectors of performance. Available at: https://appsso.eurostat.ec.europa.eu/nui/show.do

Hrytsenko, L. L., Roienko, V. V., \& Boiarko, I. M. (2018). Institutional background of the role of state in investment processes activation. Financial and Credit Activity: Problems of Theory and Practice, 1(24), 338-344. [Google Scholar] [CrossRef]

Kaufmann D., Kraay A. and Mastruzzi M. (2010). The Worldwide Governance Indicators : Methodology and Analytical Issues". World Bank Policy Research Working Paper (5430). [Google Scholar]

Kaźmierczyk, J., \& Chinalska, A. (2018). Flexible forms of employment, an opportunity or a curse for the modern economy? Case study: banks in Poland. Entrepreneurship and Sustainability Issues, 6(2), 782-798. [Google Scholar] [CrossRef]

Leonov, S. V., Vasilyeva, T. A., \& Shvindina, H. O. (2017). Methodological approach to design the organizational development evaluation system. Scientific Bulletin of Polissia, 2(3(11)), 51-56. [Google Scholar] [CrossRef]

Mergel, l., \& Desouza, K. C. (2013). Implementing open innovation in the public sector: The case of Challenge.gov. Public Administration Review, 73(6), 882-890. [Google Scholar] [CrossRef]

Pajak, K., Kvilinskyi, O., Fasiecka, O., \& Miśkiewicz, R. (2017). Energy security in regional policy in Wielkopolska region of Poland. Economics and Environment, 261), 122-138. [Google Scholar]

Pimonenko, T., Yu, M., Korobets, O., \& Lytvynenko, O. (2017). Ecological stock indexes: foreign experience and lessons for Ukraine. Bulletin of Sumy State University. Economy Ser, 4, 121-127.

Rathgeb Smith, S (2010). Nonprofits and public administration: Reconciling performance management and citizen engagement. American Review of Public Administration, 40(2), 129-152. [Google Scholar] [CrossRef]

Scupola, A., \& Zanfei, A. (2016). Governance and innovation in public sector services: The case of the digital library. Government Information Quarterly, 33(2), 237-249. [Google Scholar] [CrossRef]

The Global Innovation Index (GII) (2012-2019). Available at: https://www.globalinnovationindex.org/analysis-indicator

The Global Sustainability Competitiveness Index. (2012-2019). Available at: http://solability.com/the-global-sustainablecompetitiveness-index/the-index

Tkachenko, V., Kwilinski, A., Klymchuk, M., \& Tkachenko, I. (2019a). The economic-mathematical development of buildings construction model optimization on the basis of digital economy. Management Systems in Production Engineering, 27(2), 119-123. [Google Scholar] [CrossRef

Tkachenko, V., Kwilinski, A., Korystin, O., Svyrydiuk, N., Tkachenko, I. (2019b). Assessment of information technologies influence on financial security of economy. Journal of Security and Sustainability, 8(3), 375-385. [Google Scholar] [CrossRef]

Tolbert, C. J., Mossberger, K., \& McNeal, R. (2008). Institutions, policy innovation, and E-Government in the American States. Public Administration Review, 68(3), 549-563. [Google Scholar] [CrossRef]

Vasilyeva, T. A., \& Makarenko, I. A. (2017). Modern innovations in corporate reporting. Marketing and Management of Innovations, (1), 115-125. [Google Scholar] [CrossRef]

Vasyl'eva, T. A., Leonov, S. V., \& Makarenko, I. O. (2017). Modern methodical approaches to the evaluation of corporate reporting transparency. Scientific bulletin of Polissia, 2(1(9)), 185-190. [Google Scholar] [CrossRef]

Vasylieva, T. A., \& Kasyanenko, V. O. (2013). Integral assessment of innovation potential of Ukraine's national economy: A scientific methodical approach and practical calculations. Actual Problems of Economics, 144(6), 50-59. 
V. Kondratenko, O. Okopnyk, L. Ziganto, A. Kwilinskii. Innovation Development of Public Administration: Management and Legislation Features

Vasylieva, T. A., Leonov, S. V., Kryvych, Y. N., \& Buriak, A. V. (2017a). Bank 3.0 concept: global trends and implications. Financial and credit activity: problems of theory and practice, 1(22), 4-10. [Google Scholar]

Vasylieva, T. A., Lieonov, S. V., Petrushenko, Y. M., \& Vorontsova, A. S. (2017b). Investments in the system of lifelong education as an effective factor of socio-economic development. Financial and credit activity: problems of theory and practice, 2(23), 426-436. [Google Scholar] [CrossRef]

Yevdokimov, Y., Chygryn, O., Pimonenko, T., \& Lyulyov, O. (2018). Biogas as an alternative energy resource for Ukrainian companies: EU experience. Innovation Marketing, 14, 7-15. [Google Scholar] [CrossRef]

Віталій Кондратенко, д.ю.н., доцент, Центральноукраїнський державний педагогічний університет імені Володимира Винниченка (Україна);

Олена Окопник, к.ю.н., доцент, Центральноукраїнський державний педагогічний університет імені Володимира Винниченка (Україна);

Лінда Зіганто, Ph.D., Університет Юрая Добрили в Пулі (Хорватія);

Олексій Квілінський, Ph.D., Лондонська академія науки і бізнесу (Великобританія).

Інноваційний розвиток і ефективність публічного управління: правові та управлінські аспекти

У статті проаналізовано вплив ефеективності державне управління на інноваційний розвиток країни. 3 метою виявлення основних наукових напрямів дослідження авторами проведено бібліометричий аналіз наукових публікацій, що досліджують питання ефективності державного управління. Для аналізу обрано 1167 наукових статей, які проіндексовано наукометричною базою даних Scopus. Для візуалізації результатів бібліометричного аналізу використано програмне забезпечення VOSviewer. На основі отриманих результатів виокремлено десять наукових кластерів вчених, які досліджували питання взаємозв'язку інноваційного розвитку країни та ефективності державного управління. Перший найбільший кластер наукових публікацій - «інноваційний розвиток» сфокусований на дослідженні ефективності державного управління та впровадженні інновацій. Другий кластери пов'язаний з аналізом ефективності державної інноваційної політики. Третій кластер - державне управління» вміщує понад сорок ключових слів та 4699 посилань. Визначено, що найбільша питома вага наукових публікацій опублікована вченими з італійською та американською афіляцією. При цьому Європейські фонди профінансували найбільшу питому вагу наукових досліджень за визначеною тематикою. У рамках статті висунуто гіпотезу про зв'язок між рівнями інноваційного розвитку та ефективності державного управління в країні. Перевірку гіпотези здійснено з використанням кореляційного аналізу, моделі найменших квадратів та програмного забезпечення EViews 11. У якості показників оцінювання ефективності державного управління використано світові показники ефективності державного управління (Worldwide Governance Indicators). Об'єктом дослідження обрано країни ЄС та України. Отримані емпіричні результати підтвердили наявність кореляції між обраними змінними параметрами. Так, підвищення ефективності державного урядування та посилення верховенства права призводять до підвищення рівня інноваційного розвитку країни на 0,094 та 0,043 пункту відповідно. У той же час посилення регуляторної політики провокуе зростання рівня інноваційного розвитку країни на 0,08 пункту. Встановлено, що рівень сталої конкурентоспроможності країни та обсяг витрат на дослідження та розробки мали не значний статистично значущий вплив на індекс інноваційного розвитку країни. На основі результатів аналізу емпіричних даних проведено систематизацію підходів до підвищення ефективності державного управління та відповідного правового забезпечення. Враховуючи досвід ЄС, авторами визначено заходи, впровадження яких сформує передумови для підвищення ефективності державного управління, а саме: удосконалення законодавчої бази щодо регулювання права власності, синхронізація вітчизняних антикорупційних директив з нормами ЄС, проведення цифровізаціі державних органів влади на всіх рівнях. Для подальших досліджень доцільно збільшити часовий проміжок та вибірку країн, що дозволить отримати більш об'єктивні емпіричні дані.

Ключові слова: управління, менеджмент, нормативна база, право власності, інновації.

Manuscript received: 01.10.2019.

(C) The author(s) 2020. This article is published with open access at Sumy State University. 